\title{
CONDITIONS OF SAFE SHIP OPERATION IN SEAPORTS - OPTIMIZATION OF PORT WATERWAY PARAMETERS
}

\author{
Stanisław Gucma \\ Maritime University of Szczecin, Poland
}

\begin{abstract}
A seaport is presented in this article as a system composed of various types of waterways. The author has defined relationships between port waterway system elements and conditions of safe operation of ships in port. Relationships were determined between the conditions of safe operation of ships and the parameters of the following port waterways: anchorage, fairways (approach and inner channels, port entrances), turning area and port basin. The identified relationships between port waterway system and conditions of safe ship operation provided a basis for formulating the objective function of waterway parameter optimization during port design. In practice, these relations were used to determine the parameters of the Outer Container Terminal being built in Świnoujście, where two optimization problems were to be solved:

1. The optimization of approach channel parameters,

2. The optimization of parameters of the port entrance, turning area and port basin.

The Outer Container Terminal in Świnoujście is expected to handle ocean-going ships with a length overall $L_{o}=400 \mathrm{~m}$, and its projected capacity is estimated at 1.5 million TEU per year, a figure that can be doubled in the future.
\end{abstract}

Keywords: marine traffic engineering, sea port, waterways, optimization of port parameters, simulation methods of optimization.

\section{INTRODUCTION}

The seaport is a system consisting of set of various waterways (harbour areas) such as: anchorages, fairways, turning areas and basins. The parameters of individual types of waterways are a function of the safe operation of ships manoeuvring in these waterways [Gucma S. 2015].

Conditions for the safe operation of ships are defined by basic parameters of a 'maximum ship' that can safely maneuver on a given waterway in the allowable for this manoeuvre hydrometeorological conditions. Conditions for the safe operation of ships in particular types of waterways differ and are otherwise determined.

Conditions for the safe operation of ships in port regarded as a system composed of various types of waterways are dependent on the conditions of safe operation of ships on each specific waterway within the port, while the parameters of each waterway belonging to the port are determined by the conditions of safe operation of ships manoeuvring in that area.

The article defines and determines the above relations, i.e.:

- conditions for safe operation of ships manoeuvring in a port as a waterway system,

- conditions for safe operation of port waterways,

- relationships between port waterway parameters and the conditions for their safe operation.

These relationships enable optimisation of port parameters, i.e. the functional division of the port, formulation of the objective function of the functional parts and the optimization of individual waterways, components of the port.

The defined dependencies of waterway parameters on the conditions for safe operation of the port and port waterways 
were used in the optimization of the parameters of the Outer Container Terminal under construction in Świnoujście.

\section{THE SEAPORT AS A SYSTEM COMPOSED OF VARIOUS WATERWAYS}

The seaport in terms of marine traffic engineering is a system consisting of a set of the following types of waterways (port areas), where ships perform characteristic maneuvers (Fig.1):

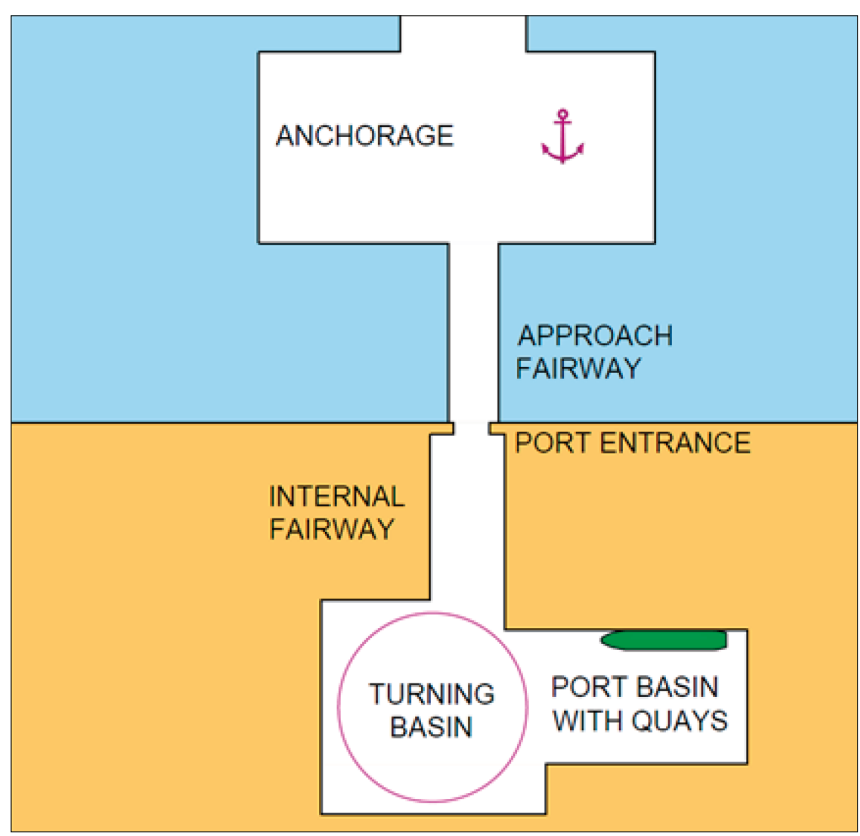

Fig. 1. System of port waterways

- anchorage (roadstead) - anchoring manoeuvre,

- approach channel - passage along the channel,

- port entrance - port entry manoeuvre

- internal fairway (port channel) - port channel passage manoeuvre,

- turning basin - turning maneuver

- port basin and berth - berth approach and berthing manoeuvres.

In the port regarded as a system of sea waterways, different port areas make up separate waterway sections that can be classed by a number of criteria [Gucma S. et al.: 2015]:

- technical parameters of the port area,

- technical parameters of navigation systems used,

- prevailing hydrometeorological conditions,

- conditions of safe operation.

Each of the sections of the waterway is composed of two basic elements [Gucma S. 2014]:

1. waterway subsystem,

2. navigational subsystem (ship position determination subsystem).

These elements affect each other and have an important impact on the system properties.
The parameters of elements (subsystems) of each port waterway section define conditions for safe operation of ships in the port system. Therefore, the vector of the conditions of safe ship operation is a function of the port waterway system parameters:

where

$$
\boldsymbol{W}_{i}=F\left[\begin{array}{l}
\boldsymbol{A}_{i} \\
\boldsymbol{N}_{i}
\end{array}\right]
$$

$W_{i}$ - vector of safe ship operating conditions in i-th section of the port waterway,

$\boldsymbol{A}_{i}$ - subsystem of the area (the $i$-th section of the port waterway),

$N_{i}$ - navigational subsystem (of $i$-th section of the port waterway).

Conditions for the safe operation of ships in ports are subject to two restrictions [IMO 2002; Tsinker G.P. 2004; Thoresen C.A. 2014; Gucma S. 2015]:

1. The principal maximum parameters (length, breadth, draft) of vessels that can safely enter the port must be the same in all waterway sections,

2. Hydrometeorological conditions that allow ships to manoeuvre are identical for all port waterway sections except for anchorage (roadstead).

Sea going ferries are considered separately, as allowable hydro - meteorological conditions for ferries are stricter and established individually for each ferry, depending on their parameters and manoeuvrability.

Given the above limitations, conditions for safe operation of ships in port regarded as a waterway system can be written in the form of a vector [Gucma S. 2015]:

$$
\boldsymbol{W}^{p}=\left[L_{o}, B, T, \boldsymbol{H}^{p}\right]
$$

where:

$W^{p}$ - vector of safe ship operating conditions for the whole port as a waterway system,

$L_{o} \quad$ - maximum length overall of the ship that can safely enter the port,

$B$ - maximum breadth of the ship that can safely enter the port,

$T$ - maximum draft of the ship that can safely enter the port,

$\boldsymbol{H}^{p}$ - set of hydrometeorological conditions acceptable for port manoeuvres of a 'maximum ship', i.e. ship whose at least parameter: $L_{o}, B, T$ has the maximum value. wherein:

$$
\boldsymbol{H}^{p}=\left[s, V_{w}, V_{c}, \Delta h\right]
$$

where:

$s \quad$ - allowable visibility,

$V_{w}$ - allowable wind speed,

$V_{c}^{w}$ - allowable current speed,

$\Delta h$ - allowable drop of water level.

For anchorages, values $V_{w}, V_{c}$ and $\Delta h$ are adopted without restrictions concerning the conditions prevailing in the anchorage area. 


\section{CONDITIONS OF THE SAFE OPERATION OF SHIPS IN PORT WATERWAYS}

The subsystems of port waterway areas $\left(\boldsymbol{A}_{i}\right)$ and the vectors of safe ship operating conditions $\left(\boldsymbol{W}_{i}\right)$ are defined differently depending on the type of waterway, which involves different kind of manoeuvres performed by the ship. Port waterways are divided into four differently defined groups: These are:

1. Anchorages,

2. Fairways, approach channels, innner channels and port entrances

3. Turning basins,

4. Port basins with quays (berths).

An anchorage is defined by two system components (area and navigation subsystems), which are a function of the conditions of safe operation of vessel performing anchoring manoeuvre:

$$
\left[\begin{array}{c}
\boldsymbol{A}^{a} \\
\boldsymbol{N}^{a}
\end{array}\right]=f\left(\boldsymbol{W}^{a}\right)
$$

The anchorage area subsystem is described by a set of parameters:

where:

$$
\boldsymbol{A}^{a}=\left[\begin{array}{c}
\boldsymbol{D}^{a} \\
h^{a}
\end{array}\right]
$$

$D^{a}$ - available navigable area of the anchorage (meeting a condition of minimum depth),

$h^{a}$ - minimum depth of anchorage.

The navigation subsystem of the anchorage is defined by a set of parameters:

where:

$$
\boldsymbol{N}^{a}=\left[\begin{array}{c}
M_{o j} \\
m_{j}
\end{array}\right]
$$

$M_{o j}$ - circular error of ship position determined at anchorage using the $j$-th navigation system,

$m_{j} \quad$ - availability of $j$-th navigational system at any time of day for various visibility conditions.

The conditions of safe ship operation at anchorage during anchoring manoeuvres and staying at anchor are expressed by the vector of the 'maximum ship' safe operating conditions.

$$
\boldsymbol{W}^{a}=\left[L_{o}, B, T, \boldsymbol{H}^{a}\right]
$$

where:

$\boldsymbol{H}^{a}$ - the set of hydrometeorological conditions acceptable for manoeuvring of a 'maximum ship' at anchorage.

The set of allowable hydrometeorological conditions of anchoring $\boldsymbol{H}^{a}$ is limited for some anchorages only by allowable maximum wind speed $\left(V_{w}^{a}\right)$ and allowable water level drop $\left(\Delta h^{a}\right)$; in such a case:

$$
\boldsymbol{H}^{a}=\left[V_{w}^{a}, \Delta h^{a}\right]
$$

Fairways and port entrances, like anchorages, are defined by the area and navigation subsystems, a function of the conditions of safe operation of vessels manoeuvring therein.

$$
\left[\begin{array}{c}
\boldsymbol{A}_{i}^{f} \\
\boldsymbol{N}_{i j}^{f}
\end{array}\right]=f_{1}\left(\boldsymbol{W}_{i}^{f}\right)
$$

The area subsystem is described by this set of parameters:

$$
\boldsymbol{A}_{i}^{f}=\left[\begin{array}{l}
t_{i} \\
l_{i} \\
D(l)_{i} \\
h_{i}
\end{array}\right]
$$

where:

$t_{i} \quad-$ type of $i$-th fairway section,

$l$. - length of $i$-th fairway section,

$D(l)_{i}$ - width of the available navigable area of $i$-th fairway section as a function of its length,

$h_{i} \quad-$ minimum depth of $i$-th fairway section.

From the viewpoint of marine traffic engineering, the following types of waterways are distinguished in this group [Gucma S. et al.: 2015]:

- fairway:

- straight section,

- bend,

- entrance to the port (straight, a bend or combined bends).

The navigation subsystem of the fairway is described by a set of parameters:

$$
\mathbf{N}_{i j}^{f}=\left[\begin{array}{l}
p(l)_{i j} \\
m_{i j} \\
n_{i j} \\
w_{i j}
\end{array}\right]
$$

where:

$p(l)_{i j}$ - accuracy of $j$-th navigational system in $i$-th section of the fairway defined as a function of fairway length $l$ (directional error perpendicular to the fairway centre line at a specific level of confidence),

$m_{i j} \quad$ - availability of $j$-th navigational system in $i$-th section of the fairway (dependent on the day/night time, visibility and ownership of the system),

$n_{i j} \quad$ - reliability of the $j$-th navigational system in $i$-th section of the fairway (technical reliability),

$w_{i j} \quad$ - integrity of the $j$-th navigational system in $i$-th section of the fairway (measure of confidence in the correctness of information provided by the system).

The conditions of safe ship operation in a fairway are described by a set of conditions for the safe operation of a maximum ship in $i$-th section of the fairway, which is written as [Gucma S. et al.: 2015]

$$
\boldsymbol{W}_{\mathrm{i}}^{f}=\left[t_{y p}, L_{o}, B, T, H_{s t}, V_{i}, C_{i}, \boldsymbol{H}_{\mathrm{i}}^{f}\right]
$$

where

$t_{y p} \quad$ - type of 'maximum ship',

$H_{s t} \quad$ - airdraft of 'maximum ship' (for passage under bridges),

$V_{i} \quad$ - allowable speed of 'maximum ship' in $i$-th fairway section, 
$C_{i} \quad-$ tug assistance in $i$-th section of the fairway, if it is required (required number and bollard pull of tugs),

$\boldsymbol{H}_{\mathrm{i}}^{f} \quad$ - set of hydrometeorological conditions acceptable for a 'maximum ship' in $i$-th waterway section.

$$
\boldsymbol{H}_{\mathrm{i}}^{f}=\left[d / n, s, \Delta h_{i}, V_{w i}, V_{p i}, h_{f i}\right]
$$

where:

$\mathrm{d} / \mathrm{n}$ - allowable time of day (day or no restrictions),

s - allowable visibility,

$\Delta h_{i}$ - allowable drop of water level in the $i$-th section of the fairway,

$h_{w i} \quad$ allowable wave height in $i$-th section of the fairway.

Conditions of the safe ship operation, defining the parameters of marine waterway system components, are defined separately for one-way and two-way traffic. For twoway traffic the conditions of safe fairway operation can be written as follows:

$$
\left[\begin{array}{c}
\boldsymbol{A}_{i}^{f} \\
\boldsymbol{N}_{i}^{f}
\end{array}\right]=\boldsymbol{f}_{2}\left[\begin{array}{c}
t_{y p}^{\text {in }}, L_{c}^{\text {in }}, B^{\text {in }}, T^{\text {in }}, V^{\text {in }} C_{i}^{\text {in }} \boldsymbol{H}_{\mathrm{i}}^{f} \\
t_{y p}^{\text {out }}, L_{o}^{\text {out }}, B^{\text {out }}, T^{\text {out }}, V^{\text {out }} C_{i}^{\text {out }} \boldsymbol{H}_{\mathrm{i}}^{f}
\end{array}\right]
$$

whereby in means a ship entering the port and out refers to a departing ship.

Turning basins, like anchorages and fairways, are defined by two elements, which are a function of the conditions of safe operation of vessels manoeuvring therein:

$$
\left[\begin{array}{l}
\boldsymbol{A}^{t} \\
\boldsymbol{N}^{t}
\end{array}\right]=f\left(\boldsymbol{W}^{t}\right)
$$

The subsystem of the turning basin is defined similarly to the anchorage area subsystem, that is:

$$
\boldsymbol{A}^{t}=\left[\begin{array}{c}
\boldsymbol{D}^{t} \\
h^{t}
\end{array}\right]
$$

the navigational subsystem, similarly to the fairway, i.e.:

where:

$$
\boldsymbol{N}^{t}=\left[\begin{array}{c}
M_{o j} \\
m_{j} \\
n_{j} \\
w_{j}
\end{array}\right]
$$

$M_{o j}$ - accuracy of $j$-th navigational system (circular error of position).

The conditions of the safe ship operation in a turning basin are defined by the vector of maximum ship safe operating conditions:

$$
\boldsymbol{W}^{t}=\left[L_{o}, B, T, \boldsymbol{H}^{t}\right]
$$

while the set of allowable conditions of a turning manoeuvre can be written as follows:

$$
\boldsymbol{H}^{t}=\left[d / n, s, \Delta h, V_{w}, V_{c}\right]
$$

A port basin with quays is defined by three subsystems: area, navigation, quay, which are a function of the conditions of safe operation of vessel manoeuvring therein.

$$
\left[\begin{array}{l}
\boldsymbol{A}^{b p} \\
\boldsymbol{N}^{b p} \\
\boldsymbol{K}^{b p}
\end{array}\right]=f\left(\boldsymbol{W}^{b p}\right)
$$

The subsystem of the port basin is defined by a set of parameters, like in the case of turning area:

$$
\boldsymbol{A}^{b p}=\left[\begin{array}{c}
\boldsymbol{D}^{b p} \\
h^{b p}
\end{array}\right]
$$

The navigation subsystem is defined similarly to that of fairways, except that the accuracy of the $j$-th navigational system is represented by the directional error of ship position, perpendicular to the berth line and the error of speed evaluation, the normal to the berth line.

The subsystem of berth and its equipment is described by a set of parameters:

where:

$$
\boldsymbol{K}_{i}^{b p}=\left[\begin{array}{c}
T_{i} \\
k_{i} \\
b_{i} \\
E_{i} \\
q_{i} \\
v_{i}
\end{array}\right]
$$

$T_{i}$ - type of the structure of $i$-th berth,

$k_{i}$ - length of the line of mooring of $i$-th berth,

$b_{i} \quad$ - fender spacing at $i$-th berth,

$E_{i}$ - allowable kinetic energy absorbed by the fender at $i$-th berth,

$q_{i} \quad$ - allowable reaction force on $1 \mathrm{~m}^{2}$ of the fender front panel on $i$-th berth (allowable unit pressure on the hull),

$v_{i} \quad$ - allowable speed of propeller streams at the bottom of the approach area.

The conditions for the safe operation of a 'maximum ship' manoeuvring in a port basin and coming to a given berth are written as a vector:

$$
\boldsymbol{W}^{b p}=\left[r, L_{o}, B, T, H_{s t}, F, M, M_{s l}, n_{h}, U_{h}, H^{b p}\right]
$$

where:

$r \quad$ - type of maneuvers of the maximum ship coming to a given berth,

$F \quad$ - lateral windage of 'maximum ship',

$M$ - main propulsion power of 'maximum ship',

$M_{s t}$ - power of bow thrusters of 'maximum ship',

$n_{h}{ }^{s t}$ - number of tugs assisting the berthing of 'maximum ship',

$U_{h}$ - total bollard pull of tugs involved in berthing,

$\boldsymbol{H}^{b p}$ - the set of hydrometeorological conditions acceptable during manoeuvring of 'maximum ship' to a given berth. 
Hydrometeorological conditions permitted for berthing manoeuvres of the 'maximum ship' are defined similarly to the case of fairway passage:

Specifying the conditions of safe ship operation in the port waterway system we distinguish the following berthing manoeuvres, also dependent on the number of propellers and thrusters of the ship [Clark I.C. 2009]:

- twin-propeller ships with bow thrusters - berthing without assistance,

- single-propeller ships with bow thrusters - berthing without assistance,

- single-propeller ships without thrusters - berthing without assistance.

- ships berthing with tug assistance.

Depending on the type of berthing ships the vector of safe operating conditions may be written in various ways (different set of parameters).

\section{PORT PARAMETER OPTIMIZATION: THE CASE OF OUTER CONTAINER TERMINAL CONSTRUCTION IN ŚWINOUJŚCIE}

The optimization of parameters of a typical port including anchorage, approach channel, port entrance, turning basin and port basin is performed in two parts:

- optimization of parameters of the approach channel,

- optimisation of parameters of the port basin and turning basin.

The common characteristics of both optimisation procedures are:

- conditions of safe ship operation:

$$
\boldsymbol{W}^{p}=\left[L_{o^{\prime}}, B, T, \boldsymbol{H}^{p}\right]
$$

- the expected traffic intensity of ingoing vessels:

$$
\boldsymbol{I}=\left[I_{l}, I_{m}, I_{s}\right]
$$

which is usually determined for vessel size groups: large $\left(I_{l}\right)$, medium $\left(I_{m}\right)$ and small $\left(I_{s}\right)$. This division depends on the projected port capacity and calling ships.

When the port parameter optimization problems are divided into two parts, port entrance is combined with approach channel in cases where ships manoeuvre on their own, or with port and turning basins if ships are to manoeuvre assisted by tugs.

The parameters of an anchorage are usually determined and optimized separately. Anchorage parameters, such as capacity (horizontal dimensions) and minimum depth are a function of the conditions of the safe operation of maximum ships at the anchorage, projected vessel traffic intensity and associated time of ship delays [Groenveld R., Hoek C.V.A. 2000].
For the purpose of optimizing parameters of a newly designed outer container port in Świnoujście, safe operation conditions for ingoing ships were determined as follows:

$$
\text { type Lo B T }
$$

$\boldsymbol{W}^{p}=\left[\right.$ container ship, $\left.400 \mathrm{~m}, 60 \mathrm{~m}, 13.0 \mathrm{~m}, \boldsymbol{H}^{p}\right]$

while the allowable hydrometeorological conditions for the entry of maximum ships into that port can be written as follows (no res. - no restrictions):

$$
\mathrm{d} / \mathrm{n} \quad \mathrm{s} \quad \Delta \mathrm{h} \quad \mathrm{Vw} \quad \mathrm{Vp} \quad \mathrm{hf}
$$

$\boldsymbol{H}^{p}=$ [no res., $1 \mathrm{Nm}, 0.5 \mathrm{~m}, 10 \mathrm{~m} / \mathrm{s}, 1 \mathrm{knot}$, no res.] (27)

To determine the parameters of the outer container port in Świnoujście two optimisation problems were solved:

1. optimization of the port entrance parameters (with tugs), turning area and port basin including the berth,

2. optimization of the approach channel parameters.

Such a set of problems results from a differently formulated objective function and different methods used to solve them.

The optimization of parameters: port entrance, turning basin and port basin with berths of the Outer Container Terminal in Świnoujście.

Objective functions for this type of sea waterways system can be written this form [Gucma S., Ślączka W. 2015; Gucma S. et al. 2015]:

$$
Z=(A+N+S) \rightarrow \min
$$

with the constraints:

- safety of ship manoeuvring (one of two), - condition of navigational safety:

$$
\begin{aligned}
& \mathbf{d}_{i k z(1-\alpha)} \subset \mathbf{D} \\
& \left.\widehat{h_{x y} \geq T_{x y}+\Delta_{x y(1-\alpha)}}\right\} \\
& p(x, y) \in \mathbf{D}(t)
\end{aligned}
$$

- condition of the navigational risk:

$$
R_{i} \leq R_{a k c}
$$

- safety of ship's mooring.

-condition of the allowable wave height:

$$
h_{w} \leq h_{w a k c}
$$

where:

$Z$ - cost of the construction and operation of the waterways system,

A - cost of the construction (reconstruction) of a waterway,

$N$ - construction cost of ship position determination subsystem (navigation systems), 
$S \quad-$ ship's operating costs associated with the passage through the waterway (waiting for passage, pilotage, tug assistance, etc.),

$D_{i}(t)$ - navigable area in $i$-th section of the waterway (condition of safe depth at instant $t$ is satisfied),

$\mathbf{d}_{i k z(1-\alpha)}$ - safe maneuvering area of $k$-th ship performing a maneuver in $i$-th section of the waterway in $z$-th navigational conditions determined at the confidence level $1-\alpha$,

$R_{i} \quad$ - navigational risk when passing $i$-th section of the waterway,

$R_{a k c} \quad$ - acceptable navigational risk,

$h_{x y}^{a k c} \quad-$ area depth at point $(x, y)$,

$T_{x y} \quad-$ ship's draft at point $(x, y)$,

$\Delta_{x y(1-\alpha)}$ - underkeel clearance at point $(x, y)$ determined at the confidence level $1-\alpha$,

$h_{w} \quad-$ wave height at berth,

$h_{\text {wakc }}$ - wave height acceptable for a particular vessel at berth.

The costs of construction of the port waterway system of the outer container terminal in Świnoujście depend on the size of the navigable area $(\boldsymbol{D})$, depth of that area $\left(h_{x y}\right)$ and the sheltering breakwater length $\left(l_{b r}\right)$, therefore we can write:

$$
Z=F\left(D, h_{x y}, l_{b r}\right) \rightarrow \min
$$

In the particular case of Świnoujście Outer Container Terminal the area depth was determined by the depth of Pomeranian Bay and accepted as equal to $h_{x, y}=14.5 \mathrm{~m}$. In this connection the objective function can be written as:

$$
Z=F\left(\boldsymbol{D}, l_{b r}\right) \rightarrow \min
$$

with two constraints:

- safety of manoeuvring ships:

$$
d_{i(1-\alpha)} \square \boldsymbol{D}_{i}
$$

- safety of mooring ships:

$$
h_{w} \leq h_{w a k c}
$$

The parameter optimization of the Outer Container Terminal made use of a method specially developed for the purpose - a two-stage simulation method of optimization [Report...2017]. In this method the safe maneuvering area $\left(\mathbf{d}_{i k z(1-\alpha)}\right)$ was determined on the basis of simulation test results conducted on full mission bridge simulators with $3 \mathrm{D}$ visualization, operated at the Marine Traffic Engineering Centre in Szczecin. Wave heights at berths were determined on the basis of wave analysis carried out using mathematical models developed at the IBW PAN (Polish Academy of Sciences).

Figure 2 presents the optimal shapes and parameters of the entrance, turning basin and berths of the Outer Container Terminal in Świnoujście.

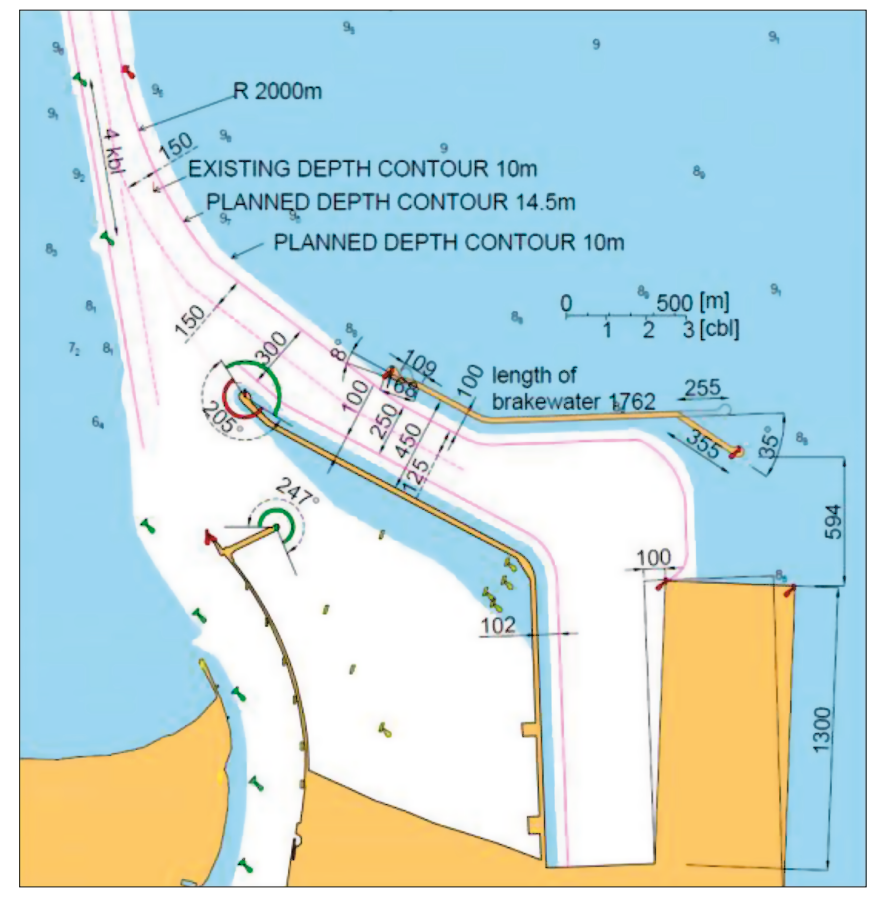

Fig. 2. Outer Container Terminal in Świnoujście dimensioned as a result of parameter optimization of the entrance, turning area and the mooring basin (navigable area $\mathbf{D}$ is bounded by a red line) [Report Maritime University of Szczecin (2017): Detailed specification of parameters and conditions for safe operation of the Świnoujście Outer Container Port.]

The optimization of parameters of the approach channel leading to the Outer Container Terminal in Świnoujście.

The objective function applied in optimisation problems related to parameters of a fairway composed one-way and two-way sections is to minimise the cost of its construction and operation costs accounting for delays of ships for each size group and projected traffic intensity can be written as follows [Gucma S. et. al. 2015; Gucma L. et. al. 2016]:

$$
Z_{r}=\left(A_{r}+N_{r}+K_{s}\right) \rightarrow \min
$$

with the constraints dependent on the type of fairway traffic: - one-way fairway,

$$
\left.\begin{array}{r}
D_{j} \geq \mathrm{d}_{\mathrm{j}(1-\alpha)}+2 \mathrm{~d}_{\mathrm{r}} \\
h \geq T+\Delta
\end{array}\right\}
$$

- two-way fairway,

$$
\left.\begin{array}{r}
D_{j} \geq d_{j(1-\alpha)}^{\text {in }}+d_{j(1-\alpha)}^{\text {out }}+d_{r}^{\text {in }}+d_{r}^{\text {out }}+d_{r}^{s} \\
h \geq T+\Delta
\end{array}\right\}
$$

$Z_{r} \quad-$ annual construction costs of waterway (fairway) system and annual costs of ship delays,

$A_{r} \quad-$ annual depreciation of the fairway (construction costs divided by 30 years of depreciation period),

$N_{r} \quad$ - annual depreciation of non-autonomous navigation systems (construction costs of these systems divided by 15 years of depreciation period), 


$$
\begin{aligned}
& K_{s} \quad-\text { annual delay costs for ships using the designed } \\
& \text { fairway, } \\
& D_{j} \quad \text { - available width of the fairway at the bottom }
\end{aligned}
$$

Annual costs of the delays of ships using a specific variant of the fairway design are calculated from this relationship:

$$
K_{s}=\sum_{l=1}^{n} l_{l} \cdot t_{l} \cdot k_{l}
$$

where

$l_{l} \quad-$ projected number of ships in $l$-th group using the designed waterway within one year,

$t_{l} \quad-$ mean time of delay of $l$-th group ship,

$k_{l} \quad-$ unit costs of delay of $l$-th group ship.

Annual costs of delays of ships using the real variant of the designed waterway construction are calculated by the method of computer simulation of vessel traffic flows (for 10 year vessel traffic forecast).

The solution of the objective function resulted in an optimal division of the approach channel into the following sections (Fig. 3):

- one-way traffic, $2.1 \mathrm{~km} \div 11.0 \mathrm{~km}$ of the fairway,

- two-way traffic $11.0 \mathrm{~km} \div 35.6 \mathrm{~km}$ of the fairway (buoy N2).

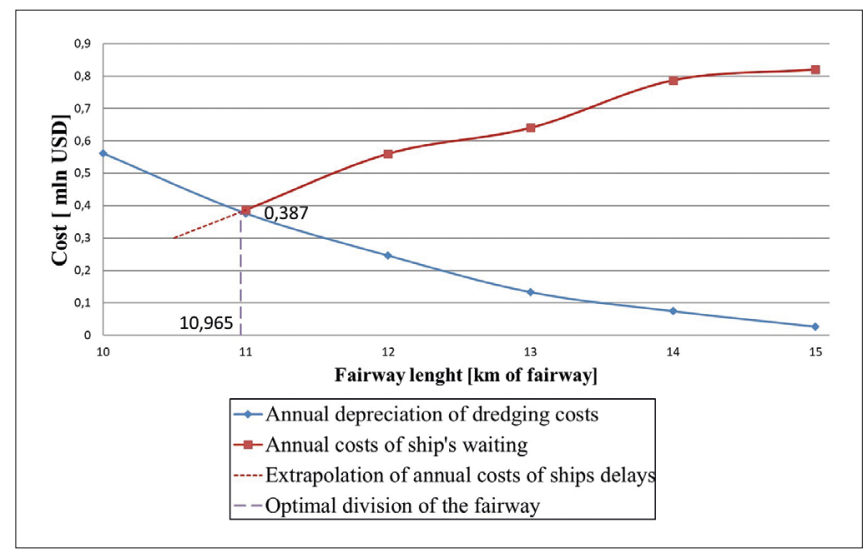

Fig. 3. The optimal length of two-way approach channel to Świnoujście (from buoy N2 to $11 \mathrm{~km}$ point of the channel) [Report Maritime University of Szczecin (2017): Detailed specification of parameters and conditions for safe operation of the Świnoujście Outer Container Port.]

The navigable width at the bottom in the approach channel to the Outer Container Terminal in Świnoujście determined by empirical relationships [PIANC 2014; Zalewski P. 2012] is, respectively:
- one-way section $(2.1 \mathrm{~km} \div 11.0 \mathrm{~km}) \mathrm{D}=220 \mathrm{~m}$,

- two-way section $(11,0 \mathrm{~km} \div 35,6 \mathrm{~km}$ of $) \mathrm{D}=500 \mathrm{~m}$.

\section{SUMMARY}

The article defines the port as a system composed of set of various waterways (anchorage, approach channel, entrance to the port, turning basin, and port basin with berths). The conditions have been specified for safe ship operation in port waterway system and in particular types of port waterways. In this connection, relationships between the parameters of individual types of waterway and conditions of safe operation of ships have been defined. Based on these relations, the objective function of two port optimization problems has been calculated.

- optimization of parameters of the port entrance, turning basin and port basin with berths,

- optimization of parameters of the approach channel.

The optimal division of an approach channel into one-way and two-way sections is made by the method of computer simulation of vessel traffic flows.

Optimal parameters of the port entrance, turning basin and port basin are determined using dedicated two-phase simulation optimisation methods, in which simulation experiments are carried out on a ship-handling simulator with $3 \mathrm{D}$ visualization.

The developed methods have been used to determine optimal parameters of the Outer Container Terminal currently under construction in Świnoujście, where the annual container handling capacity is estimated at 1.5 million TEU. The port is expected to operate ocean-going container ships with a length overall $L_{c}=400 \mathrm{~m}$ and breadth $B=60 \mathrm{~m}$.

\section{REFERENCES}

1. Gucma L., Bąk A., Sokołowska S., Hajduk J. (2016): Stochastic model of ship traffic congestion in waterways applied to determine the influence of Liquefied Petroleum Gas tanker introduction on ship traffic on the Swinoujście-Szczecin waterway. Scientific Journal of Maritime University of Szczecin No. 45 (117), 2016.

2. Gucma S. (2014): System approach to sea waterways. Scientific Journal of Maritime University of Szczecin No. 38(110)2014.

3. Gucma S. (2015): Port basin as waterway system component. Scientific Journals of the Maritime University of Szczecin, No. 41(113)2015.

4. Gucma S. et al. (2015): Morskie Drogi Wodne. Projektowanie i eksploatacja w ujęciu inżynierii ruchu morskiego. Fundacja Promocji Przemysłu Okrętowego i Gospodarki Morskiej, Gdańsk. 
5. Gucma S., Ślączka W. (2015): Methods for optimization of sea waterway systems and their application. Polish Maritime Research, No. 3(87)2015 Gdańsk.

6. PIANC (2014): Harbour Approach Channels Design Guidelines. PIANC Report No. 121-2014 PIANC Secretariat General. Bruxelles.

7. Report Maritime University of Szczecin (2017): Detailed specification of parameters and conditions for safe operation of the Świnoujście Outer Container Port.

8. Thoresen C.A. (2014): Port Designer's Handbook ICE Publishing. London.

9. Tsinker G.P. (2004): Port Engineering. Planning, construction, Maintenance, and Security. John Wiley and Sons, INC.

10. Zalewski P. (2012): Algorithms for analytical method of waterway design parameters determination; Scientific Journals of the Maritime University of Szczecin No. 29(101)2012.

11. Groenveld R., Hoek C.V.A. (2000): A simulation tool to assess nautical safety in port approaches, Seminar of the Permanent Commission for Development and Cooperation of PIANC, Argentina.

12. International Maritime Organization (IMO, 2002): Resolution Standards for Ship Maneuverability, MSC.137(76) 4.

13. Clark I.C. (2009): Mooring and anchoring ships, Vol 1 (Principles and Practice) The Nautical Institute, London.

\section{CONTACT WITH THE AUTHORS}

\section{Stanisław Gucma}

e-mail:s.gucma@am.szczecin.pl

Maritime University of Szczecin

Wały Chrobrego 1-2

70-500 Szczecin

POLAND 